\title{
REPORT ON THE FIFTEENTH ANNIVERSARY of Alcide De Gasperi University OF EUROREGIONAL ECONOMY
}

\section{Sprawozdanie Z XV-Lecia Wyższej Szkoly GOSPODARKI EUROREGIONALNEJ}

W dniu 13 października 2017 r. Wyższa Szkoła Gospodarki Euroregionalnej im. Alcide De Gasperi świętowała 15. rocznicę powołania oraz Inaugurację Roku Akademickiego 2017/2018.

Uroczysta gala jubileuszowa odbyła się w Powiatowym Młodzieżowym Domu Kultury w Otwocku dzięki przychylności pani Dyrektor Ewy Musiejko.

Wydarzenie poprowadzili mgr Iwona Florek - pełnomocnik dziekana, oraz dr Łukasz Roman - adiunkt na Wydziale Nauk Społecznych. Spotkanie uświetniły występy muzyczne studentów Uniwersytetu Muzycznego w Warszawie im. Fryderyka Chopina: Katarzyny Jankowskiej - śpiew, Szymona Orlińskiego - fortepian, i studenta Politechniki Warszawskiej Wojciecha Sitka - skrzypce.

Zebranych gości powitała oraz uroczystość otworzyła pani prof. dr hab. Magdalena Sitek - prorektor Uczelni.

Uczelnia nasza rozpoczęła swoja działalność 18 listopada 2002 roku. (...) Pomimo wielu przeciwności losu uczelnia istnieje i dynamicznie się rozwija. Dotychczas Uczelnię ukończyło około pięciu tysięcy absolwentów, w tym około dwustu pięćdziesięciu z zagranicy. Obecnie na naszej uczelni studiują studenci nie tylko $z$ Polski, ale z piętnastu krajów świata. To świadczy o dobrej kondycji Uczelni 
i nadziei na jej przyszłość w coraz trudniejszej sytuacji na rynku edukacyjnym. Uczelnia $w$ okresie 15 lat swojego istnienia wspótpracowała z jednostkami samorządu lokalnego, organizując cztery Fora Gospodarcze Powiatu Otwockiego oraz wspóttworząc Klub Nowej Gospodarki Powiatu Otwockiego.

Następnie prof. dr hab. Bronisław Sitek zaprezentował jubileuszową publikację będącą dziełem zbiorowym pracowników WSGE, a ukazującą ostatnie 5 lat działalności Uczelni.

Z okazji tak ważnego jubileuszu Prezydent RP odznaczył na wniosek Ministra Nauki i Szkolnictwa Wyższego orderami pracowników WSGE za wzorowe, wyjątkowo sumienne wykonywanie obowiązków wynikających z pracy zawodowej.

Złoty medal zasługi otrzymał pan Janusz Bukanowski - kierownik działu administracyjno-gospodarczego związany z WSGE od początku istnienia. Brązowe medale zasługi otrzymały: pani dr Małgorzata Such-Pyrgiel - Dziekan Wydziału Nauk Społecznych oraz pani mgr Magdalena Augustyniak - kierownik Biblioteki.

Ponadto troje pracowników WSGE zostało uhonorowanych medalami Komisji Edukacji Narodowej za pracę na rzecz dzieci i młodzieży: dr Małgorzata Kaniewska, dr Dorota Łażewska oraz dr Aleksandra Szejniuk.

Medale wręczył, z upoważnienia Ministra Nauki i Szkolnictwa Wyższego oraz Przewodniczącego Komisji Edukacji Narodowej, pan Rafał Rogala - Szef Urzędu do spraw Cudzoziemców.

Pan minister podkreślił rolę uczelni jako miejsce do wspólnej wymiany pomysłów i rozwiązań między przedstawicielami świata akademickiego, osobami z sektora prywatnego, a także przedstawicielami sektora publicznego.

Następnie pani Bożena Żelazowska - Przewodnicząca Komisji Kultury i Dziedzictwa Narodowego Sejmiku Województwa Mazowieckiego, Radna Województwa Mazowieckiego wyróżniła pracowników WSGE: dra Tadeusza Gracę, prof. WSGE - Rektora, dr hab. Magdalenę Sitek, prof. WSGE - Prorektora, mgra inż. Jana Jakimowicza - Pełnomocnika Kanclerza, prof. zw. dra hab. Bronisłwa Sitka, mgr Grzegorza Laskowskiego, Beatę Zawadkę - Zastępcę Kierownika Dziekanatu, Dominikę Mrozińską - Referenta w Dziekanacie oraz mgr Martę Bojaruniec - Dyrektor Biura Współpracy Zagranicznej, którzy szczególnie wyróżnili się oraz przyczynili się do rozwoju szkoły, wręczając 
dyplomy pamiątkowe, oraz wręczyła Medal Pamiątkowy „Pro Masovia” dla WSGE za całokształt działalności oraz zasługi na rzecz województwa mazowieckiego na ręce JM Rektora dra Tadeusza Gracy.

Pani Przewodnicząca zaznaczyła, że to już 15 lat, jak na terenie naszego Powiatu Otwockiego w przepięknej miejscowości Józefów działa wyższa szkoła, która niewątpliwie ma wiele zasług, integruje środowisko powiatu, promuje nasze miejscowości nie tylko na Mazowszu, ale w całym kraju i za granica.

Kilkoro z zebranych gości zabrało głos.

Pan Paweł Rupniewski, wicestarosta Powiatu Otwockiego, rozpoczął nieco sentymentalnie: pomimo że nie jestem absolwentem tej uczelni, ma ona dla mnie specyficzne, bardzo sentymentalne znaczenie. (...) Moja przygoda $z$ samorządem zbiegła się z czasem, kiedy ta uczelnia rozpoczęła swoja działalność na terenie Józefowa. (...)

Wyższa Szkoła Gospodarki Euroregionalnej zdecydowanie należy do grona uczelni, którym udało się oparcie swojej marki na trzech filarach. Znamiennym jest, że ideę integracji o zasięgu ponadnarodowym, której orędownikiem był patron uczelni - Alcide De Gasperi - Władze Uczelni realizuja w skali lokalnej, gromadzac wokół siebie osoby, którym zależy na podniesieniu swoich kwalifikacji zawodowych, kompetencji oraz zakresu posiadanej wiedzy. Jest to wspólnota ludzi, często o odmiennych poglądach $i$ wartościach, ale ukierunkowanych na jeden cel, jakim jest rozwój regionu. Należy podkreślić wytrwałość władz uczelni w konsekwentnej realizacji obranego przez siebie kierunku. Dzięki doskonałemu zrozumieniu i wykorzystaniu zarówno lokalnych, jak i zewnętrznych zasobów ludzkich Uczelnię opuszczają absolwenci przygotowani do pełnienia roli integratorów swoich własnych społeczności.

Armando Costa - Burmistrz Miasta Bitetto, z którym WSGE owocnie współpracuje od lat, powiedział: Przyjechałem, aby pogratulować piętnastu lat funkcjonowania uczelni, życzyć wszystkiego najlepszego. Cieszę się, że właśnie na tej uczelni studiują studenci z różnych krajów świata, tym samym uczelnia ta staje się istotnym elementem na drodze do budowania braterstwa między narodami.

Po części jubileuszowej miała miejsce akademicka część uroczystości, czyli Inauguracja Roku Akademickiego połączona z dyplomatorium, której przewodniczył JM Rektor dr Tadeusz Graca. 
Wybranych 15 studentów pierwszego roku dostąpiło uroczystej immatrykulacji, ślubując, że będą wytrwale dążyć do zdobywania wiedzy i rozwoju własnej osobowości, szanować prawa i obyczaje akademickie oraz całym swoim postępowaniem dbać o honor i godność studenta Wyższej Szkoły Gospodarki Euroregionalnej im. Alcide De Gasperi z siedzibą w Józefowie.

W imieniu Kierownictwa Uczelni, Senatu, nauczycieli akademickich, pracowników administracji oraz swoim własnym życzę Wam wszystkim szczęścia oraz wszelkiej pomyślności, życzę wytrwałości $w$ zdobywaniu wiedzy, przede wszystkim bardzo dobrych ocen $w$ indeksach oraz zadowolenia $z$ wybranej przez siebie drogi życiowej - powiedział JM Rektor dr Tadeusz Graca.

W konkursie na najlepszą pracę wyróżnionych zostało trzech absolwentów:

- Abdumalik Ashurov za pracę „The banking system of Tajikistan” napisaną pod kierownictwem dra Nicolasa Leviego;

- Beata Łuczak za pracę „Retencja personelu w aspekcie zarządzania kapitałem ludzkim na przykładzie hoteli Sheraton i Westin” napisaną pod kierownictwem dr Aleksandry Szejniuk;

- Mirosław Dąbrowski za pracę „Nadzór nad rynkiem finansowym napisaną pod kierownictwem dra Pawła Sitka.

Rektor pogratulował absolwentom oraz promotorom za wysoki poziom merytoryczny prac.

Po odśpiewaniu hymnu „Gaudeamus Igitur” zebrani mieli możliwość wysłuchania bardzo ciekawego wykładu inauguracyjnego nt. „Dylematy zarządzania Policją" wygłoszonego przez prof. zw. dra hab. Stanisława Pieprznego z Uniwersytetu Rzeszowskiego.

Uroczystość zakończyła się poczęstunkiem i rozmowami w kuluarach. 